\title{
A Novel Photoelectrochemical Glucose Sensor Based on Graphene-CdS Nanocomposites Decorated with $\mathrm{CoO}_{\mathrm{x}}$ Nanosheets
}

\author{
Zhimin Ma, Sujuan $\mathrm{Li}^{*}$ \\ Henan Province Key Laboratory of New Optoelectronic Functional Materials, College of Chemistry \\ and Chemical Engineering, Anyang Normal University, Anyang, 455000, Henan, China \\ *E-mail: 1emontree88@163.com
}

doi: $10.20964 / 2019.12 .71$

Received: 7 July 2019 / Accepted: 24 September 2019 / Published: 29 October 2019

In this work, visible light driven enzyme-free glucose PEC sensor was developed by electrochemically deposited $\mathrm{CoO}_{\mathrm{x}}$ nanosheets on graphene-CdS nanocomposites modified electrode to achieve both the electrocatalytic and photoelectrocatalytic oxidation of glucose at the resultant $\mathrm{CoO}_{\mathrm{x}} /$ graphene-CdS nanocomposites modified electrode. Scanning electron microscopy, electrochemical impedance spectroscopy and cyclic voltammetry were used to characterize the morphology and electrochemical properties of the resultant $\mathrm{CoO}_{\mathrm{x}} /$ graphene-CdS nanocomposites. The $\mathrm{CV}$ results demonstrated that decoration of $\mathrm{CoO}_{x}$ nanosheets largely enhanced the photoelectrocatalytic activity of graphene-CdS composites toward glucose oxidation in alkaline solution. The glucose detection sensitivity under visible light irradiation is dramatically improved compared to dark condition. Good performance was obtained for the $\mathrm{CoO}_{x} /$ graphene-CdS nanocomposites based glucose sensor. The feasibility of the present method was confirmed by good recovery results for glucose detection in human urine samples.

Keywords: Graphene; CdS nanowires, Cobalt oxide nanosheet, Glucose, Photoelectrochemical sensor.

\section{$\underline{\text { FULL TEXT }}$}

(C) 2019 The Authors. Published by ESG (www.electrochemsci.org). This article is an open access article distributed under the terms and conditions of the Creative Commons Attribution license (http://creativecommons.org/licenses/by/4.0/). 